\title{
Improving the acidic perspiration fastness of Eucalyptus bark dye with dye levelling agents on cotton
}

\author{
R. PRABHAVATHI, A. SHARADA DEVI AND D. ANITHA
}

Received: 08.05.2017; Revised: 07.10.2017; Accepted: 21.10.2017

See end of the paper for authors' affiliations

\section{R. PRABHAVATHI}

Department of Apparel and Textiles

College of Home Science, Saifabad,

Acharya N.G. Ranga Agricultural

University, HYDERABAD

(TELANGANA) INDIA
ABSTRACT : This paper reports the improving the acidc perspiration fastness of Eucalyptus bark dye on cotton mordanted with eco-friendly mordants and post-treated with various leveling agents. The natural dye with dye levelling agents, extraction of the colourants from natural sources; effects of different mordants and mordanting methods; selection of $\mathrm{f}$ levelling agents; dyeing variables; post-treatment process and analysis of colour improvement parameters with levelling agsents for cotton dyed with natural dye; assessed colour improvement with colour fastness test.

KEY WORDS: Eucalyptus bark natural dye, Levelling agents, Colourfastness, Eco-friendly mordants, Acidic perspiration

- HOW TO CITE THIS PAPER : Prabhavathi, R., Devi, A. Sharada and Anitha, D. (2017). Improving the acidic perspiration fastness of Eucalyptus bark dye with dye levelling agents on cotton. Asian J. Home Sci., 12 (2) : 444-447, DOI: 10.15740/HAS/AJHS/12.2/444-447. 